\title{
Reassignment of Actinobacillus actinomycetemcomitans to the Genus Haemophilus as Haemophilus actinomycetemcomitans comb. nov.
}

\author{
T. V. POTTS, ${ }^{1.2 *}$ J. J. ZAMBON ${ }^{2}$ AND R. J. GENCO ${ }^{2}$ \\ Departments of Operative Dentistry ${ }^{1}$ and Oral Biology, ${ }^{2}$ School of Dentistry, State University of New York at Buffalo, \\ and the Periodontal Disease Clinical Research Center, Buffalo, New York 14214
}

\begin{abstract}
Serological techniques were used to assess the relationships among the following species: Actinobacillus equuli, Actinobacillus lignieresii, Actinobacillus pleuropneumoniae, "Actinobacillus seminis," Actinobacillus suis, Actinobacillus actinomycetemcomitans Haemophilus aphrophilus, Haemophilus paraphrophilus, Haemophilus segnis, Haemophilus parainfluenzae, Haemophilus influenzae, Haemophilus parahaemolyticus, Haemophilus aegyptius, and Gardnerella vaginalis. Deoxyribonucleic acid-deoxyribonucleic acid hybridization analyses of $A$. actinomycetemcomitans, $H$. segnis, $H$. aphrophilus, and $H$. paraphrophilus showed that these four species have measurable deoxyribonucleic acid relatedness of $28 \%$ or greater, consistent with their placement in a single genus. These bacterial species also demonstrated common antigens by immunodiffusion. In view of these genetic and serological relationships and previous inclusion of $\mathrm{X}$ - and $\mathrm{V}$-factor-independent bacterial species in the genus Haemophilus, reassignment of $A$. actinomycetemcomitans to the genus as Haemophilus actinomycetemcomitans comb. nov, is proposed.
\end{abstract}

The morphological and cultural characteristics of Actinobacillus actinomycetemcomitans were first described by Klinger (12) in 1912. The initial isolates of this gram-negative facultative anaerobe were from actinomycotic lesions and were given the name "Bacterium actinomycetemcomitans." The name of this organism was subsequently changed twice, first by Lieske (13) in 1921 to "Bacterium comitans" and then by Topley and Wilson (31) in 1929 to Actinobacillus actinomycetemcomitans.

The first detailed description of the biochemical and serological characteristics of this species was published by King and Tatum (11), who compared A. actinomycetemcomitans with Haemophilus aphrophilus and found these species to be closely related. More recently, a number of studies have delineated the phenotypic $(1,6,8,10,19,26$, $29)$, serological $(24,27,33,34)$, and deoxyribonucleic acid (DNA)-DNA hybridization characteristics $(2,4,20,22,30)$ of A. actinomycetemcomitans.

The purpose of the DNA-DNA hybridization work reported here was to further delineate the relationships among A. actinomycetemcomitans, Haemophilus segnis, Haemophilus aphrophilus, and Haemophilus paraphrophilus. Serological studies were carried out to further evaluate the relationships among the following species: Actinobacillus equuli, Actinobacillus lignieresii, Actinobacillus pleuropneumoniae, "Actinobacillus seminis," Actinobacillus suis, A. actinomycetemcomitans, $H$. aphrophilus, $H$. segnis, H. paraphrophilus, Haemophilus parainfluenzae, Haemophilus influenzae, Haemophilus paraphrohaemolyticus, Haemophilus aegyptius, and Gardnerella vaginalis.

\section{MATERIALS AND METHODS}

Bacterial strains and culture conditions. The bacterial strains used in the production of rabbit antisera are shown in Table 1. Strains of Actinobacillus and Haemophilus species were grown to late logarithmic or early stationary phase in National Institutes of Health thioglycolate liquid medium

\footnotetext{
* Corresponding author.
}

(Difco Laboratories, Detroit, Mich.). X- and V-factor-requiring strains were grown on chocolate agar for $72 \mathrm{~h}$. All strains were grown at $37^{\circ} \mathrm{C}$ in an anaerobic chamber (Coy Manufacturing Co., Ann Arbor, Mich.) containing $85 \% \mathrm{~N}_{2}, 10 \% \mathrm{H}_{2}$, and $5 \% \mathrm{CO}_{2}$. The bacteria grown in liquid media were harvested by centrifugation and washed three times in phosphate-buffered saline $(\mathrm{pH}$ 7.2). The strains grown on agar plates were harvested with a platinum loop and washed three times in phosphate-buffered saline.

Antiserum production. Whole bacterial cells to be used as immunogens were suspended in sterile saline to a concentration of $10 \mathrm{mg}$ (wet weight) per ml. Eight-week-old female New Zealand white rabbits weighing $4 \mathrm{~kg}$ received intravenous injections of $1.0 \mathrm{ml}$ of bacterial suspensions via the marginal ear vein; the protocol of McCarty and Lancefield was used (17). For each strain, antisera were produced in two or more rabbits. Trial blood samples were obtained from the central ear artery, and the antibody titers were determined by immunodiffusion. Once a satisfactory antibody titer had been obtained, the rabbits were exsanguinated by cardiac puncture. The antisera were heated to $56^{\circ} \mathrm{C}$ for 30 min and stored in small portions at $-76^{\circ} \mathrm{C}$ until they were used.

Sonic extraction of bacterial cell antigens. Whole bacterial cells (100 mg, wet weight) were placed in $15 \mathrm{ml}$ of phosphatebuffered saline in an ice bath and sonicated with a model 350 Sonifier cell disrupter (Bronson Sonic Power Co., Danbury, Conn.) at $25 \mathrm{~W}$ with a tapered microtip having an end diameter of $3 \mathrm{~mm}$ (model 419; Heat Systems Ultrasonics, Plainview, N.Y.) until more than $95 \%$ of the cells were disrupted, as determined by phase-contrast microscopy. The sonic extracts were centrifuged at $12,000 \times g$ for $30 \mathrm{~min}$ at $4^{\circ} \mathrm{C}$, and the supernatants were removed, dialyzed overnight against distilled water, and lyophilized. The sonic extracts were then suspended to a protein concentration of $25 \mathrm{mg} / \mathrm{ml}$, as determined by the assay of Lowry et al. (14), and stored at $-20^{\circ} \mathrm{C}$ until they were used.

Immunodiffusion. Immunodiffusion was carried out in $1.2 \%$ agarose (SeaKem ME; FMC Corp., Rockland, Maine) in $0.033 \mathrm{M}$ Veronal buffer ( $\mathrm{pH} 8.2$ ) by the method of 
TABLE 1. Actinobacillus, Gardnerella, and Haemophilus species used in the preparation of rabbit antisera, bacterial sonic extracts, and bacterial DNA

\begin{tabular}{|c|c|c|c|}
\hline Species & Strain & Serotype & Source $^{n}$ \\
\hline \multirow[t]{8}{*}{ A. actinomycetemcomitans } & ATCC 29522 & & ATCC \\
\hline & ATCC 29523 & & ATCC \\
\hline & ATCC 29524 & & ATCC \\
\hline & NCTC 9709 & & NCTC \\
\hline & NCTC $9710^{\mathrm{T}}$ & & NCTC \\
\hline & Y4 & b & Socransky \\
\hline & 75 & a & SUNYaB \\
\hline & 67 & $\mathrm{c}$ & SUNYaB \\
\hline A. equali & ATCC $19392^{\mathrm{T}}$ & & ATCC \\
\hline A. lignieresii & ATCC 19393 & & ATCC \\
\hline \multirow[t]{3}{*}{ A. pleuropneumoniae ${ }^{h}$} & ATCC $27088^{\mathrm{T}}$ & & ATCC \\
\hline & ATCC 27089 & & ATCC \\
\hline & ATCC 27090 & & ATCC \\
\hline "A. seminis" & ATCC 15768 & & ATCC \\
\hline A. suis & ATCC 15557 & & ATCC \\
\hline G. vaginalis & ATCC $14018^{\mathrm{T}}$ & & ATCC \\
\hline H. aegyptius & ATCC $11116^{\mathrm{T}}$ & & ATCC \\
\hline \multirow[t]{4}{*}{ H. aphrophilus } & ATCC 13252 & & ATCC \\
\hline & ATCC 19415 & & ATCC \\
\hline & NCTC $5906^{\mathrm{T}}$ & & NCTC \\
\hline & NCTC 5908 & & NCTC \\
\hline \multirow[t]{7}{*}{ H. influenzae } & ATCC 19418 & & ATCC \\
\hline & ATCC 9006 & a & ATCC \\
\hline & ATCC 9795 & $b$ & ATCC \\
\hline & ATCC 9007 & $\mathrm{c}$ & ATCC \\
\hline & ATCC 9332 & $\mathrm{~d}$ & ATCC \\
\hline & ATCC 8142 & $\mathrm{e}$ & ATCC \\
\hline & ATCC 9833 & $\mathrm{f}$ & ATCC \\
\hline H. parahaemolyticus & ATCC $10014^{\mathrm{T}}$ & & ATCC \\
\hline \multirow[t]{2}{*}{ H. parainfluenzae } & ATCC 7901 & & ATCC \\
\hline & ATCC 9796 & & ATCC \\
\hline H. paraphrohaemolyticus & ATCC $29237^{\mathrm{T}}$ & & ATCC \\
\hline \multirow[t]{3}{*}{ H. paraphrophilus } & ATCC 29240 & & ATCC \\
\hline & ATCC $29241^{\mathrm{T}}$ & & ATCC \\
\hline & ATCC 29242 & & ATCC \\
\hline H. segnis & NCTC $10977^{\mathrm{T}}$ & & NCTC \\
\hline
\end{tabular}

"ATCC, American Type Culture Collection, Rockville, Md.: NCTC, National Collection of Type Cultures, London, United Kingdom: Socransky, S. S. Socransky, Forsyth Dental Center, Boston, Mass.; SUNYaB, State University of New York at Buffalo, Buffalo, N.Y.

${ }^{b}$ This species was recently transferred to the genus Actinobacillus from the genus Haemophilus (21).

Ouchterlony (18). All combinations of bacterial cell sonic extracts and rabbit immune sera were examined. The negative controls included preimmune rabbit sera.

DNA purification and DNA-DNA homology. DNA was isolated and purified, and the guanine-plus-cytosine content of each DNA was measured by the melting point method (15). DNA-DNA hybridization reactions were carried out at $25^{\circ} \mathrm{C}$ below the melting temperature of the probe DNA. Experiments in which either $A$. actinomycetemcomitans ATCC $9710^{\mathrm{T}}(\mathrm{T}=$ type strain) or $H$. aphrophilus ATCC $5906^{\mathrm{T}}$ DNA was used as the probe were carried out at $63^{\circ} \mathrm{C}$; experiments in which $H$. segnis ATCC $10977^{\mathrm{T}}$ DNA was used as the probe were conducted at $61^{\circ} \mathrm{C}$. In all other respects, the hybridization reactions were carried out exactly as described previously (23); the S1 nuclease method was used for measuring DNA-DNA homoduplexes (3).

\section{RESULTS}

Table 2 shows DNA-DNA hybridization data for representative strains of $H$. segnis, $H$. aphrophilus, $H$. paraphrophilus, and A. actinomycetemcomitans. Three tritium- labeled probes were used in these experiments to determine the reciprocal hybridization values for reactions in which cold $H$. segnis ATCC $10977^{\mathrm{T}}$ DNA was used. All of the DNAs tested hybridized at a level of $28 \%$ or greater with the labeled test probes. For each reciprocal pair of labeled and unlabeled DNAs, the results were in close agreement.

The results of serological experiments are shown in Table 3. Antiserum to A. pleuropneumoniae (formerly Haemophilus pleuropneumoniae) reacted only with antigenic extracts from six Haemophilus species and G. vaginalis. Antigenic extracts from $A$. pleuropneumoniae cross-reacted only with antibodies directed against four Haemophilus species and $G$. vaginalis. Antiserum directed against A. actinomycetemcomitans reacted with at least one antigenic determinant on four species belonging to the genus Actinobacillus, as well as with four members of the genus Haemophilus. In the reciprocal experiments, antisera directed against each of these eight reactive species cross-reacted with one $A$. actinomycetemcomitans antigen. The only two other crossreactions between the groups of haemophili and actinobacilli studied were observed with $H$. aphrophilus; antiserum directed against $H$. aphrophilus reacted with one $A$. suis antigen, whereas antiserum directed against $A$. lignieresii reacted with one $H$. aphrophilus antigen. Among $A$. actinomycetemcomitans, $H$. aphrophilus, $H$. paraphrophilus, $H$. segnis, and $H$. parainfluenzae, all antigen preparations reacted with antisera directed against each of the other species, with the exception of the $H$. parainfluenzae antigen preparation, which did not react with antiserum directed against $H$. aphrophilus. Antiserum directed against $H$. parainfluenzae reacted with all of the Haemophilus strains tested, as well as with $A$. actinomycetemcomitans and $G$. vaginalis.

\section{DISCUSSION}

King and Tatum (11) recognized long ago that the species A. actinomycetemcomitans more closely resembled $H$. aphrophilus than $A$. lignieresii, the type species of the genus Actinobacillus. Several additional investigations have verified the close phenotypic relationship between $A$. actinomycetemcomitans and $H$. aphrophilus $(8,10,26,29)$, and Zambon et al. (33) and McArthur et al. (16) have shown that there are antigenic similarities between these two organisms. By the same token, a very close phenotypic relationship has been noted between $H$. aphrophilus and $H$. paraphrophilus $(8,9,28)$. Common antigens have also been reported for $A$. actinomycetemcomitans and $H$. para-

TABLE 2. Results of DNA-DNA hybridization experiments

\begin{tabular}{lccc}
\hline Source of unlabeled DNA Homology with the following labeled DNA \\
probes:
\end{tabular}

${ }^{a}$ Mean \pm standard deviation. The numbers in parentheses are the numbers of times the experiment was performed.

${ }^{b}$ Data previously published by Potts and Berry (19). 
TABLE 3. Serological relationships among Actinobacillus, Haemophilus, and Gardnerella species

\begin{tabular}{|c|c|c|c|c|c|c|c|c|c|c|c|c|c|c|c|c|}
\hline \multirow[b]{2}{*}{$\begin{array}{l}\text { Rabbit anti- } \\
\text { sera to: }\end{array}$} & \multirow{2}{*}{$\begin{array}{l}\text { No. of } \\
\text { specific } \\
\text { anti- } \\
\text { gens }\end{array}$} & \multicolumn{15}{|c|}{ No. of common antigens in extracts of:" } \\
\hline & & $\begin{array}{c}\text { A. } \\
\text { equuli }\end{array}$ & $\begin{array}{l}\text { A. lig- } \\
\text { nieresii }\end{array}$ & $\begin{array}{c}\text { A. } \\
\text { pleur- } \\
\text { opneu- } \\
\text { moniae }\end{array}$ & $\begin{array}{l}\text { "A. se- } \\
\text { minis" }\end{array}$ & A. suis & $\begin{array}{l}\text { A. actino- } \\
\text { mycetem- } \\
\text { comitans }\end{array}$ & $\begin{array}{l}\text { H. aph- } \\
\text { rophi- } \\
\text { lus }\end{array}$ & $\begin{array}{l}\text { H. seg- } \\
\text { nis }\end{array}$ & $\begin{array}{l}\text { H. par- } \\
\text { aphro- } \\
\text { philus }\end{array}$ & $\begin{array}{l}\text { H. par- } \\
\text { ain- } \\
\text { fluen- } \\
\text { zae }\end{array}$ & $\begin{array}{l}\text { H. in- } \\
\text { fluen- } \\
\text { atae }\end{array}$ & $\begin{array}{c}\text { H. par- } \\
\text { ahae- } \\
\text { molyti- } \\
\text { cus }\end{array}$ & $\begin{array}{l}\text { H. paraph- } \\
\text { rophacmo- } \\
\text { lyticus }\end{array}$ & $\begin{array}{l}\text { H. ae- } \\
\text { gyptius }\end{array}$ & $\begin{array}{l}\text { G. l'ag- } \\
\text { inalis }\end{array}$ \\
\hline A. equuli & 1 & & 1 & 0 & 1 & 1 & 1 & 0 & 0 & 0 & 0 & 0 & 0 & 0 & 1 & 0 \\
\hline A. lignieresii & 1 & 1 & & 0 & 1 & 1 & 1 & 1 & 0 & 0 & 0 & 0 & 0 & 0 & 0 & 0 \\
\hline $\begin{array}{l}\text { A. pleuro- } \\
\text { pneumo- } \\
\text { niae }\end{array}$ & 1 & 0 & 0 & & 0 & 0 & 0 & 0 & 1 & 1 & 1 & 2 & 2 & 0 & 1 & 1 \\
\hline $\begin{array}{l}\text { "A. se- } \\
\text { minis" }\end{array}$ & 2 & 1 & 1 & 0 & & 1 & 1 & 0 & 0 & 0 & 0 & 0 & 0 & 0 & 0 & 0 \\
\hline A. suis & 1 & 1 & 1 & 0 & 1 & & 1 & 0 & 0 & 0 & 0 & 0 & 0 & 0 & 0 & 0 \\
\hline $\begin{array}{l}\text { A. actinomy- } \\
\text { cetemco- } \\
\text { mitans }\end{array}$ & 2 & 1 & 1 & 0 & 1 & 1 & & 1 & 1 & 1 & 1 & 0 & 0 & 0 & 0 & 0 \\
\hline $\begin{array}{l}\text { H. aphrophi- } \\
\text { lus }\end{array}$ & 1 & 0 & 0 & 0 & 0 & 1 & 1 & & 1 & 1 & 0 & 0 & 0 & 0 & 0 & 0 \\
\hline H. segnis & 1 & 0 & 0 & 0 & 0 & 0 & 1 & 1 & & 1 & 1 & 1 & 0 & 0 & 0 & 0 \\
\hline $\begin{array}{l}\text { H. paraph- } \\
\text { rophilus }\end{array}$ & 1 & 0 & 0 & 0 & 0 & 0 & 1 & 1 & 1 & & 1 & 1 & 0 & 0 & 0 & 0 \\
\hline $\begin{array}{l}\text { H. parain- } \\
\text { fluenzae }\end{array}$ & 2 & 0 & 0 & 2 & 0 & 0 & 1 & 1 & 1 & 1 & & 2 & 2 & 2 & 1 & 1 \\
\hline $\begin{array}{l}\text { H. influen- } \\
\text { zae }\end{array}$ & 1 & 0 & 0 & 1 & 0 & 0 & 0 & 0 & 0 & 1 & $1-2$ & & 1 & $1-2$ & 1 & 1 \\
\hline $\begin{array}{l}\text { H. parahae- } \\
\text { molyticus }\end{array}$ & 1 & 0 & 0 & 1 & 0 & 0 & 0 & 0 & 1 & 1 & 1 & 1 & & 0 & 1 & 1 \\
\hline $\begin{array}{l}\text { H. paraph- } \\
\text { rohaemo- } \\
\text { lyticus }\end{array}$ & 1 & 0 & 0 & 0 & 0 & 0 & 0 & 0 & 0 & 1 & 1 & $1-2$ & 0 & & 1 & 1 \\
\hline H. aegyptius & 1 & 0 & 0 & 1 & 0 & 0 & 0 & 0 & 0 & 1 & 1 & 1 & 1 & 1 & & 0 \\
\hline G. vaginalis & 2 & 0 & 0 & 1 & 0 & 0 & 0 & 0 & 0 & 1 & 1 & 1 & 1 & 1 & 0 & \\
\hline
\end{tabular}

" Maximum number of bands visible by double immunodiffusion when all of the strains listed in Table 1 were used.

phrophilus (33), but data on this point have not been presented.

A taxonomic study by Sakazaki et al. (25) verified that $A$. actinomycetemcomitans is metabolically quite different from either $A$. lignieresii or $A$. equuli. Calhoon et al. (1) have shown that there are distinct differences in the soluble protein profiles of $A$. actinomycetemcomitans and the profiles of "A. seminis," $A$. equuli, and $A$. lignieresii. In addition, Hollander et al. (6) have shown that $A$. actinomycetemcomitans, $H$. aphrophilus, $H$. paraphrophilus, and $H$. segnis produce only one respiratory quinone (dimethylmenaquinone), whereas most actinobacilli, including $A$. lignieresii, produce both dimethylmenaquinone and ubiquinone.

Several DNA-DNA hybridization studies have assessed the relationships among species of actinobacilli, including $A$. actinomycetemcomitans $(2,4,20,22,30)$. All agree that $A$. actinomycetemcomitans is distant from the type species, $A$. ligieresii, as well as the other Actinobacillus species. Escande et al. (4) have shown that organisms presently classified as $A$. lignieresii, A. equuli, Actinobacillus capsulatus, A. suis, and Pasturella ureae are related by DNA-DNA homology values of $30 \%$ or higher, suggesting that these species belong in the same genus. Of special interest is the finding of these authors that $A$. actinomycetemcomitans shares very little homology (1 to $3 \%$ ) with these species and, hence, should not be grouped with them at the genus level. Coykendall et al. (2), Potts and Berry (22), Phillips (19), and Escande et al. (4) have all suggested on the basis of DNA-DNA hybridization studies that $A$. actinomycetemcomitans should be removed from the genus Actinobacillus. On the basis of phenotypic data, Kilian (8) suggested that it might be appropriate to move this organism to the genus Haemophilus, whereas Coykendall et al. (2) and Potts and Berry (22) have made the same suggestion based on DNA-DNA hybridization results.

The DNA-DNA hybridization data presented above demonstrate that $A$. actinomycetemcomitans, $H$. aphrophilus, $H$. paraphrophilus, and $H$. segnis are related at a homology level of $28 \%$ or higher. These findings are consistent with the placement of these species in the same genus. Based strictly upon the serological results reported here, $A$. actinomycetemcomitans could fit into either the genus Actinobacillus or the genus Haemophilus. However, the other species of actinobacilli examined constitute a group of organisms which are antigenically distinct from the haemophili. When the serological data are considered together with the DNA-DNA hybridization data presented here and reported previously $(2,4,20,22,30)$, it is clear that $A$. actinomycetemcomitans, $H$. aphrophilus, $H$. paraphrophilus, and $H$. segnis should be placed in the same genus.

Table 4 shows the definitive characteristics for the genus Haemophilus (9), the genus Actinobacillus (19), and $A$. actinomycetemcomitans $(2,22,26)$. As this table shows, $A$. actinomycetemcomitans does not fulfill two of the criteria for the genus Actinobacillus due to its inability to produce either urease or $\beta$-galactosidase. On the other hand, $A$. actinomycetemcomitans does not require either $\mathrm{X}$ factor (hemin) or $\mathrm{V}$ factor (nicotinamide adenine dinucleotide); therefore, it does not fulfill the criteria for inclusion in the genus Haemophilus. However, it should be noted that $H$. 
TABLE 4. Definitive characteristics of the genus Haemophilus, the genus Actinobacillus, and A. actinomycetemcomitans ${ }^{\prime \prime}$

\begin{tabular}{lccccc}
\hline \multicolumn{1}{c}{ Taxon } & $\begin{array}{c}\text { Guanine- } \\
\text { plus-cy- } \\
\text { tosine } \\
\text { content } \\
(\mathrm{mol} \%)\end{array}$ & $\begin{array}{c}\mathrm{X} \text { - or } \\
\text { V-fac- } \\
\text { tor re- } \\
\text { quire- } \\
\text { ment }\end{array}$ & $\begin{array}{c}\beta \text {-Ga- } \\
\text { lactosi- } \\
\text { dase } \\
\text { produc- } \\
\text { tion }\end{array}$ & $\begin{array}{c}\text { Urease } \\
\text { produc- } \\
\text { tion }\end{array}$ & $\begin{array}{c}\text { Indole } \\
\text { produc- } \\
\text { tion }\end{array}$ \\
\hline $\begin{array}{l}\text { Haemophilus } \\
\text { Actinobacillus }\end{array}$ & $37-44$ & + & $+1-$ & $+1-$ & $+1-$ \\
$\begin{array}{l}\text { A. actinomy- } \\
\text { cetemcomitans }\end{array}$ & $40-43$ & - & + & + & - \\
\hline
\end{tabular}

"In addition, the members of all three taxa are gram negative, have coccobacillary morphology, reduce nitrate to nitrite, and ferment carbohydrates.

aphrophilus has been included in the genus Haemophilus despite the fact that it does not require either $\mathrm{X}$ or $\mathrm{V}$ growth factor $(8,9,28,29)$. Similarly, Haemophilus gallinarum and Haemophilus suis contain strains which do not require $\mathrm{X}$ factor for growth. With these precedents in mind and in view of the overwhelming evidence of a close relationship between $A$. actinomycetemcomitans and four species of haemophili, it seems most logical to include $A$. actinomycetemcomitans in the genus Haemophilus.

Therefore, we propose that $A$. actinomycetemcomitans be reassigned to the genus Haemophilus as Haemophilus actinomycetemcomitans comb. nov. This reassignment should serve to emphasize the taxonomic and antigenic relationships between $H$. actinomycetemcomitans and the other Haemophilus species. These relationships may be of considerable importance in clinical studies of $H$. actinomycetemcomitans, a microorganism which is thought to play an important role in the etiology of certain types of periodontal disease (32).

$H$. actinomycetemcomitans is defined as a small gramnegative coccobacillus which is nonmotile, fermentative, and capnophilic and has no requirement for either $\mathrm{X}$ or $\mathrm{V}$ factor. This organism reduces nitrate to nitrite, decomposes hydrogen peroxide, does not produce indole, and is oxidase negative. $H$. actinomycetemcomitans gives positive fermentation reactions with glucose, fructose, and mannose, but does not ferment lactose, sucrose, trehalose, or starch (26). The guanine-plus-cytosine content of this species is between 44.9 and $48.7 \mathrm{~mol} \%(2,22)$.

\section{ACKNOWLEDGMENT}

This works was supported by Public Health Service grant DE 04898 from the National Institute of Dental Research.

\section{LITERATURE CITED}

1. Calhoon, D. A., W. R. Mayberry, and J. Slots. 1981. Cellular fatty acid and soluble protein composition of Actinobacillus actinomycetemcomitans and related organisms. J. Clin. Microbiol. 14:376-381.

2. Coykendall, A. L., J. Setterfield, and J. Slots. 1983. Deoxyribonucleic acid relatedness among Actinobacillus actinomycetemcomitans, Haemophilus aphrophilus, and other Actinobacillus species. Int. J. Syst. Bacteriol. 33:422-424.

3. Crosa, J., D. Brenner, and S. Falkow. 1973. Use of a singlestrand-specific nuclease for analysis of bacterial and plasmid deoxyribonucleic acid homo- and heteroduplexes. J. Bacteriol. 115:903-911.

4. Escande, F., F. Grimont, P. A. D. Grimont, and H. Bercovier. 1984. Deoxyribonucleic acid relatedness among strains of Actinobacillus spp. and Pasteurella ureae. Int. J. Syst. Bacteriol. 34:309-315.
5. Grimont, P. A. D., M. Y. Popoff, F. Grimont, C. Coynault, and M. Lemelin. 1980. Reproducibility and correlation study of three deoxyribonucleic acid hybridization procedures. Curr. Microbiol. 4:325-330.

6. Hollander, R., A. Hess-Reihse, and W. Mannheim. 1981. Respiratory quinones in Haemophilus, Pasteurella, and Actinobacillus: pattern, function, and taxonomic evaluation, p. 83-97. In M. Kilian, W. Frederiksen, and E. L. Biberstein (ed.), Haemophilus, Pasteurella, and Actinobacillus. Academic Press, Inc., New York.

7. Johnson, J. L. 1973. Use of nucleic acid homologies in the taxonomy of anaerobic bacteria. Int. J. Syst. Bacteriol. 23:308-315.

8. Kilian, M. 1976. A taxonomic study of the genus Haemophilus, with the proposal of a new species. J. Gen. Microbiol. 93:9-61.

9. Kilian, M., and E. L. Biberstein. 1984. Genus 11. Haemophilus Winslow, Broadhurst, Buchanan, Krumweide, Rogers, and Smith 1917, 561, p. 558-569. In N. R. Krieg and J. G. Holt (ed.), Bergey's manual of systematic bacteriology, vol. 1. The Williams \& Wilkins Co., Baltimore.

10. Kilian, M., and C. R. Schiøtt. 1975. Haemophili and related bacteria in the human oral cavity. Arch. Oral Biol. 20:791-796.

11. King, E. O., and H. W. Tatum. 1962. Actinobacillus actinomycetemcomitans and Haemophilus aphrophilus. J. Infect. Dis. 111:85-94.

12. Klinger, R. 1912, Untersuchungen über menschliche Aktinomykose. Zentralblat Bacteriol. Parasitenkd. Infektionskr. Hyg. Abt. 1 Orig 62:191-200.

13. Lieske, R. 1921. Morphology und Biologie der Strahlenpilze. Borntraeger, Leipzig, Federal Republic of Germany.

14. Lowry, O. H., N. J. Rosebrough, A. L. Farr, and R. J. Randall. 1951. Protein measurement with the Folin phenol reagent. J. Biol. Chem. 193:265-275.

15. Marmur, J., and P. Doty. 1962. Determination of the base composition of deoxyribonucleic acid from its thermal denaturation temperature. J. Mol. Biol. 5:109-118.

16. McArthur, W. P., C. C. Tsai, P. Baehni, B. J. Shenker, and N. S. Taichman. 1982. Non-cytolytic effects of Actinobacillus actinomycetemcomitans on leukocyte functions, p. 179-182. In R. J. Genco and S. E. Mergenhagen (ed.), Host-parasite interactions in human periodontal diseases. American Society for Microbiology, Washington, D.C.

17. McCarty, M., and R. C. Lancefield. 1955. Variation in the group specific carbohydrates of variant strains. J. Exp. Med. 102:1-28.

18. Ouchterlony, O. 1958. Diffusion in gel methods for immunological analysis. Prog. Allergy 5:1-9.

19. Phillips, J. E. 1984. Genus 11I. Actinobacillus Brumpt 1910, 849, p. 570-575. In N. R. Krieg and J. G. Holt (ed.), Bergey's manual of systematic bacteriology, vol. 1. The Williams \& Wilkins Co., Baltimore.

20. Pohl, S. 1981. DNA relatedness among members of Haemophilus, Pasteurella, and Actinobacillus, p. 245-253. In M. Kilian, W. Frederiksen, and E. L. Biberstein (ed.), Haemophilus, Pasteurella, and Actinobacillus. Academic Press, Inc., New York.

21. Pohl, S. 1983. Transfer of Haemophilus pleuropneumoniae and the Pasteurella haemolyticus-like organism causing porcine necrotic pleuropneumonia to the genus Actinobacillus (Actinobacillus pleuropneumoniae comb. nov.) on the basis of phenotypic and deoxyribonucleic acid relatedness. Int. J. Syst. Bacteriol. 33:510-514.

22. Potts, T. V., and E. M. Berry. 1983. Deoxyribonucleic aciddeoxyribonucleic acid hybridization analysis of Actinobacillus actinomycetemcomitans and Haemophilus aphrophilus. Int. J. Syst. Bacteriol. 33:765-771.

23. Potts, T. V., L. V. Holdeman, and J. Slots. 1983. Relationships among the oral fusobacteria assessed by DNA-DNA hybridization. J. Dent. Res. 62:702-705.

24. Pulverer, G., and H. L. Ko. 1972. Serological studies on Actinobacillus actinomycetemcomitans. Appl. Microbiol. 23: 207-210.

25. Sakazaki, R., K. Tamura, S. Kuramochi, and M. Kosako. 1981. 
Numerical classification of Pasteurella and some Actinobacillus, p. 235-243. In M. Kilian, W. Frederiksen, and E. L. Biberstein (ed.), Haemophilus, Pasteurella, and Actinobacillus. Academic Press, Inc., New York.

26. Slots, J. 1982. Salient biochemical characters of Actinobacillus actinomycetemcomitans. Arch. Microbiol. 131:60-67.

27. Slots, J., J. J. Zambon, B. G. Rosling, H. S. Reynolds, L. A. Christersson, and R. J. Genco. 1982. Actinobacillus actinomycetemcomitans in human periodontal disease: association, serology, leukotoxicity, and treatment. J. Periodontal Res. 17:447-448.

28. Sneath, P. H. A., and R. Johnson. 1973. Numerical taxonomy of Haemophilus and related bacteria. Int. J. Syst. Bacteriol. 23:405-418.

29. Sutter, V. L., and S. M. Finegold. 1970. Haemophilus aphrophilus infections: clinical and bacteriologic studies. Ann. N.Y. Acad. Sci. 174:468-487.
30. Tanner, A. C. R., R. A. Visconti, S. S. Socransky, and S. C. Holt. 1982. Classification and identification of Actinobacillus actinomycetemcomitans and Haemophilus aphrophilus by cluster analysis and deoxyribonucleic acid hybridization. J. Periodontal Res. 17:585-596.

31. Topley, W. W. C., and G. S. Wilson. 1929. The principles of bacteriology and immunology. Edward Arnold and Co., London.

32. Zambon, J. 1985. Actinobacillus actinomycetemcomitans in human periodontal disease. J. Clin. Periodontol. 12:1-20.

33. Zambon, J. J., J. Slots, and R. J. Genco. 1983. Serology of oral Actinobacillus actinomycetemcomitans and serotype distribution in human periodontal disease. Infect. Immun. 41:19-27.

34. Zambon, J. J., J. Slots, K. Miyasaki, R. Linzer, R. Cohen, M. Levine, and R. J. Genco. 1984. Purification and characterization of the serotype $c$ antigen from Actinobacillus actinomycetemcomitans. Infect. Immun. 44:22-27. 